\title{
Developing assessment in improving students' digital literacy skills
}

\author{
Erlida Amnie*; Undang Rosidin; Kartini Herlina; Abdurrahman \\ Universitas Lampung \\ Jl. Prof. Dr. Ir. Sumantri Brojonegoro, Gedong Meneng, Rajabasa, Kota Bandar Lampung, Lampung \\ 35141, Indonesia. \\ *Corresponding Author. E-mail: erlida.amnie@gmail.com
}

\begin{abstract}
ARTICLE INFO ABSTRACT
Article History

Submitted:

28 July 2020

Revised:

11 January 2021

Accepted:

14 January 2021

Keywords

assessment; problem solving; digital literacy

\section{Scan Me:}

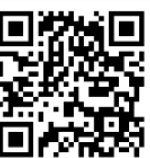

This research aims to develop an assessment of problem-solving skills in improving students' digital literacy skills. This research is directed to produce physics learning assessments that can improve students' digital literacy using problem-solving skills assessments. The use of assessments that refer to the problem-solving skills stage is expected to improve students' digital literacy. The study is an $\mathrm{R} \& \mathrm{D}$ research with the Borg and Gall development model. On the preliminary research, a questionnaire is needed to detect need analysis of an assessment that can help improving student digital literacy skills. Questionnaires were used to collect expert review data, while cognitive tests were used to collect data on students' problem-solving skills. Cognitive tests by posttest form were held to find out the progress of students understanding during the learning process using the products. The results of content validity by Aiken's $\mathrm{V}$ is 0.80 . The factor analysis is seen by the Bartlett test value with Chi-squares $=1.604$ and significance at 0.659. Therefore, the problem-solving skills assessment from the aspect of content and construction has valid criteria and is suitable for use. The N-Gain test results of students problem-solving skills in the experimental class by 0.3 with a quite effective category higher than the control class of 0.12 with a quite effective category. The results show that the use of assessment of problem-solving skills effectively improved students digital literacy skills.
\end{abstract}

This is an open access article under the CC-BY-SA license.

How to cite:

Amnie, E., Rosidin, U., Herlina, K., \& Abdurrahman, A. (2021). Developing assessment in improving students' digital literacy skills. Jurnal Penelitian dan Evaluasi Pendidikan, 25(1), 1-15.

doi:https://doi.org/10.21831/pep.v25i1.33600

\section{INTRODUCTION}

\section{Problem Solving Skills Assessment and Students Digital Literacy Skills}

Outline assessment is one of the most important parts in teaching. Educators can determine the student skill and knowledge level through assessment (Taras, 2005). The existence of the assessment is one of the main components in the learning and evaluation process. Educators make the assessment as a means of measuring the understanding achievement and the student's skill level.

Assessment has an important role in education and a critical role in the teaching process (Tosuncuoglu, 2018). Assessment is a measuring tool for the achievement of learning targets in the scope of education. Assessment is one way to improve the quality of educational outcomes. The application of assessment in learning requires a renewal of the assessment used so it makes authentic assessment an alternative assessment carried out to measure students skills.

The alternative assessment has been presented as an alternative to standard testing and all problem topics found by the assessment. This assessment is different from the traditional assessment in its activities. Assessment directs students to show what they can do (Richards \& Renandya, 2002). Authentic assessment is also known as an alternative assessment. 
The purpose of authentic assessment is to measure students's skill in answering the assignment or test given in form the problems found in real life (Frey \& Schmitt, 2007). Authentic assessment has the ability to measure students's skill trough learning process. Unfortunately, the teacher gets a difficulties to arrange the assessment. A research by Kartowagiran and Jaedun shows that only a few teachers have done authentic assessment because it must be addressed immediately, so that teachers can reveal students' real abilities.

Good authentic judgment will be able to improve the quality of learning and improve the quality of student performance, the more so, when the teacher provides feedback to the students (Kartowagiran \& Jaedun, 2016). The use of assessments is expected to improve students' learning skills. Based on the questionnaire, it can be seen that $68 \%$ of students stated that the Physics teacher gave an assessment at the end of each learning chapter. It is just that the assessment conducted by the teacher, according to the students, is still dominant in the form of a written test. Although $73 \%$ of students are aware that Physics teachers use assessments, so that students become active and engaged in thinking activities, this is still a concern. As many as $65 \%$ of students stated that they only learned the material if the teacher had given an assignment or there would be an assessment. The assessment aspects observed were dominant in students' cognitive skills. The use of assessments that are relevant to students thinking activities is not yet diverse. Thinking skills that are part of the 2013 curriculum learning component in Indonesia have not yet been realized optimally. One part is the problem-solving skills.

Problem solving was first introduced by Heller et al. (1992). Through the article, it is introduced the problem solving strategies in guiding students to have thinking skills that are more complex than cognitive. Problem solving strategies are the strategies used by Heller et al. (1992) to bring up students problem solving skills, especially high school students in that research. In their research, it has investigated how diverse the problem solving performance of high school students is after applying problem solving strategies in a physics class cooperative group. The problem solving strategy with the contextual content of the problem uses five stages, including visualizing the problem; physics description, planning a solution; executing plan; checking and evaluating. The strategies make the students have the skills to solve a problem that they have to face by learning process.

The existence of integrated problem solving skills in an assessment can also bring up other aspects of skills for students, one of them is students' skills in literacy. Literacy is one of the skills to access, understand, integrate, communicate, evaluate, and compile information obtained based on the study of sources. Source studies can be done with various types of media, including printed media, electronic media, and digital media. One kind of literacy that can be explored by problem solving skills is digital literacy.

Digital literacy has been defined by various researchers and practitioners with the same meaning, but has different focuses (Son et al., 2017). As digital technology develops in the world, understanding of digital literacy is also expanding. The focus of the meaning of digital literacy is to be richer in digital media sources that are the source of literacy information.

Digital literacy is the skills to use technology and information from digital devices effectively and efficiently in various contexts such as academics, careers and everyday life (Gilster, 1997). In line with Gilster, according to $\mathrm{Ng}$ (2012), digital literacy is related to the variety of literacy associated with the use of digital technology. This technology is divided into hardware and software that individuals use for educational, social, and entertainment purposes at school and home.

Digital literacy is rooted. It is developed in the 1980s when microcomputers became more widespread. Information literacy was widespread in the 1990s, while the information was more easily compiled, accessed, and disseminated through networked information technology (Bawden, 2001). Digital literacy should be more than just the skills to use multiple digital sources effectively. Digital literacy is also a particular form of thinking (Eshet, 2002). 
Digital literacy encompasses a wide variety of cognitive, motor, socioligical and complex emotional skills that will be needed effectively in a digital environment (Eshet, 2004). Digital literacy is very closely related to the use of digital information technology. The use of supporting applications certainly becomes a necessity in realizing life skills of the current generation.

\section{Problem Solving Skills Assessment in Improving Students Digital Literacy Skills}

This research needs to be done in realizing the learning process with the aim of eliciting students high-level thinking skills. This research was conducted as a recommendation in order to achieve a better physics learning process. The 21 st century skills observed throughout this study are the students' problem solving skills.

Problem solving skills are considered necessary to be owned by students, especially high school students, because these skills can help students make the right decisions, careful, systematic, logical, and consider various points of view. Students can carry out various activities without knowing the purpose and reason for doing so if they do not have these skills.

In general, the problem solving skills aspects consist of five indicators: students are able to define problems, examine problems, find solutions, implement plans that have been made, and evaluate (Novitasari et al., 2015). Referring to a research on problem solving strategy by Heller et al. (1992), the aspect of defining a problem is nothing but following the problem visualization (visualizing problem) stage, which is the stage where students can arrange problem statements in visual and verbal form in accordance with the condition of the problem.

The aspect of examining a problem is similar to the description stage (physics description), which is the stage that directs students to use the understanding they have to analyze the problem. The aspect of finding a solution is the same as the stage of planning a solution (planning a solution) where students begin to determine what solution is to be applied to the problem and arrange a plan in implementing the solution. The aspects of implementing a plan that have been created are similar to carrying out a plan (executing plan). Finally, the evaluation aspect follows the stages of checking and evaluating. One concept aspect of the problem solving skills used in learning today is the development of the problem solving strategy that Heller et al. (1992) have applied in their research.

The problem defining skills is student skills to determine what problems are the topic of observation. The problem checking is done by analyzing the problems that have been identified previously. Furthermore, students are directed to find solutions by referring to the results of problem analysis. The solutions that have been obtained are then planned and implemented. Students' skills in problem solving become intact after students evaluate the problem solving activities that have been carried out starting from determining the problem to the implementation of the solution.

In this study, increasing literacy skills with the assistance of digital media is the goal of developing students problem solving skills assessment assessments. This research is directed to produce physics learning assessments that can improve students digital literacy, namely by using problem solving skills assessments. The use of assessments that refer to the problem solving skills stage is expected to improve students digital literacy. The aspects of digital literacy skills that are considered during the learning implementation process by using the assessment of problem solving skills in this research are meaning making, analyzing, persona, using, decoding, creativity, operational skills, information skills, and ICT literacy.

In a complex system of class activities, assessments cannot be abstracted and used without reference to other components. Changes in assessment practice will certainly have an effect, either good or bad effect (James, 2015). Assessments always change in harmony with the changing atmosphere of teaching and learning in the post compulsory education period (Rust, 2002). The assessment relates to other components in the learning process. The development of the assessment that is used has supported the achievement of the educational targets to be 
achieved. The implementation of the 2013 curriculum at all levels and types of education currently leads to the emergence of various assessment models as an informative medium for achieving student competencies.

Authentic assessment is one of the assessments that needs to be carried out along with the ineffectiveness of traditional assessments that have often been used. Traditional assessment is considered to ignore the real world context and does not adequately describe students skills holistically.

Table 1. Digital Literacy Rubric

\begin{tabular}{|c|c|c|}
\hline No & Aspect & Dimensions \\
\hline 1 & Meaning Making & $\begin{array}{l}\text { Reading, Relating, Expressing (agency of the learner as a participant in the } \\
\text { construction of the text; reflexive process in which content, style and purpose of } \\
\text { the text is in dialogue with the prior experience knowledge and responses of the } \\
\text { reader; implies both understanding and interpretation) }\end{array}$ \\
\hline 2 & Analyzing & $\begin{array}{l}\text { Deconstructing, Selecting, Interrogating (developing the skills to make informed } \\
\text { judgements and choices in the digital domain; applying critical, aesthetic, and } \\
\text { ethical perspectives to the production and consumption of digitized material) }\end{array}$ \\
\hline 3 & Persona & $\begin{array}{l}\text { Identity Building, Managing Reputation, Participating (sensitivity to the issues of } \\
\text { reputation, identity and membership within different digital contexts; purposeful } \\
\text { management and calibration of one's online presence; developing a sense of } \\
\text { belonging and a confident participant role) }\end{array}$ \\
\hline 4 & Using & $\begin{array}{l}\text { Finding, Applying, Problem Solving, Creating (developing the skills to deploy } \\
\text { digital tools appropriately and effectively for the task in hand; solving practical } \\
\text { problems dynamically and flexibly as they arise using a range of methods and } \\
\text { approaches both individually and as part of communities) }\end{array}$ \\
\hline 5 & Decoding & $\begin{array}{l}\text { Navigation, Conventions, Operations, Stylistics, Modalities (developing familiarity } \\
\text { with the structures and conventions of digital media; sensitivity to the different } \\
\text { modes at work within digital artifacts; confidently using the operational } \\
\text { frameworks within which they exist) }\end{array}$ \\
\hline \multicolumn{3}{|c|}{ (Hinrichsen \& Coombs, 2014) } \\
\hline 6 & Creativity & $\begin{array}{l}\text { Generates content and constructs knowledge } \\
\text { Publishes and peer reviews } \\
\text { Exhibits creative thinking using digital }\end{array}$ \\
\hline 7 & Operational Skills & Develops formal computer and internet skills and navigation and orientation skills \\
\hline 8 & Information Skills & $\begin{array}{l}\text { Identifies, accesses, manages, and transforms using online public services and } \\
\text { applications }\end{array}$ \\
\hline \multicolumn{3}{|c|}{ (Jimoyiannis, 2015) } \\
\hline $\begin{array}{l}9 \\
\text { (JISC }\end{array}$ & $\begin{array}{l}\text { ICT Literacy } \\
\text { 2014) }\end{array}$ & Adopts, adapts, and uses digital devices, applications, and services \\
\hline
\end{tabular}

Authentic assessments direct students to become effective actors when gaining knowledge (Wiggins, 1990). Authentic assessment is expected to help the ongoing measurement of student learning achievement effectively from various aspects (knowledge, skills, and also attitudes). Through global assessments, it is hoped that the evaluation and decision making process will be more precise along with the precise improvement of the learning scenarios taken.

Assessment requires congruence on the learning point of view if it wants to be a valid, trusted assessment condition, to be applied to students (James, 2008). The use of assessment relates to targeted learning directions. Determination of the assessment can also consider the characteristics of the assessment to be used in learning.

Assessment can be supported by raising students' thinking skills. Problem solving skills assessment is an assessment that directs students to solve problems using what was previously understood. Problem solving skills will be unified if expressed in the form of assessments. 
This assessment leads students to recall each material learned and apply it in everyday life. Problem solving skills assessment refers to the five stages of problem solving learning strategies proposed by Heller et al. (1992) and adjusting the latest stages based on a research carried out by Novitasari et al. (2015). Successful application of problem solving skills occurs when students successfully define problems, examine problems, plan solutions, carry out plans that have been made, and evaluate (Cullinane \& Liston, 2011). Students are guided to get used to defining problems that exist during the learning process. Students are directed to examine the problem so that the skills to plan, implement, and evaluate solutions that have been stated previously was formed.

Since the existence of integrated problem solving skills in an assessment can also bring up students' skills in literacy, in this study, increasing literacy skills with the assistance of digital media is the goal of developing students' problem solving skills assessments. The indicators of achieving digital literacy skills of students refer to nine of the 20 aspects found in three different article sources. Table 1 presents an explanation of the aspects of digital literacy skills to be achieved. Thus, considering the aforementioned points and the previous related studies that have been conducted, this research aims to develop an assessment of problem-solving skills in improving students' digital literacy skills.

\section{RESEARCH METHOD}

This research was conducted to develop an assessment that guides problem solving skills in improving digital literacy of students in learning physics. This research uses research and development (R \& D) method. The development of the problem solving skills assessment was carried out considering two aspects. The first aspect to note is that there are significant differences in the problem solving skills of students before and after using problem solving skills assessment. The second aspect of using problem solving skills assessment is that there are significant differences in students digital literacy skills before and after using problem solving skills assessments.

Development is carried out with the development model of Borg and Gall (2003). The Borg \& Gall Model consists of ten stages of activities, namely: (1) research and data collection; (2) planning; (3) initial product development; (4) initial field trials; (5) revision of trial results; (6) field trials; (7) improvement of product yields; (8) field implementation test; (9) improvement of the final product; (10) dissemination and implementation. The implementation of assessment activities is carried out by the teacher following the stages that have been prepared in the assessment.

Firstly, on the research and data collection, the need analysis is a way to know what the need for improving students' digital literacy skills. In the initial stage, the researchers conduct a needs analysis to explore the problems that exist in the school, namely about what students and teachers need. Needs analysis data were taken from students and teachers using a questionnaire. This was done to determine the needs of teachers and students for problem solving skills assessment in improving student digital literacy. The material to be taught was analyzed according to the core competent and basic competent studies and student needs. Then, the results of the analysis are used as a basis in preparing the background of the problem.

At this stage, the first step was to determine the type of assessment used, taking into account the strengths and weaknesses and adjusting the needs of students. The material used as literacy material is material that has a lot of information on the development of study material on the internet as a source of digital literacy.

On the planning stage, the problem solving skills assessment was targeted as an assessment used for improving students' digital literacy skills. Meanwhile, the assessment has to bring up students' problem solving skills in a time. The problem solving skills are the skill that can be related to students' digital literacy skills. 
On the initial product development, a draft I of the product was arranged, which is an assessment referring to problem solving skills to improve student digital literacy. The product draft was then validated by expert as the intial fields trials. The initial product validation process was done by validation questionnaire. Three expert lecturers and a teacher checked the product validity. Product development validation was focused on content and design validation. Then, a one-on-one test was done to determine the product validity. The result of the assessment was obtained by calculating the total score through the validation questionnaire.

The assessment has to be tested about content validity and construct validity. Content validity can be proved by using CVR and CVI, known as V Aiken Coeficient. Lawshe (1975) proposed content validity ratio (CVR) to measure the degree of agreement between experts of one item and which can express the level of content validity through a single indicator that ranges from -1 to 1 . The CVR formula is presented in Formula (1), where ne $=$ the number of SME (Subject Matter Experts) that assess an item as 'essential', and $n=$ the number of SME who conducted the assessment (Aiken, 1985).

$$
C V R=\frac{2 n e}{n}-1
$$

Content validity can be seen by validity standard through rater frequency and the scale (Aiken, 1985). The CVR value ranges from -1 to 1. If half of the SMEs are essential, the CVR would be 0 . CVR would be worth 1 if all SMEs are essential for an item. Overall, the validity value of the test can be determined using the CVI (Content Validity Index), with the formula presented in Formula (2), where CVR = Content Validity Ratio of each item, and $\mathrm{k}=$ the number of items (Aiken, 1985).

$$
C V I=\frac{\sum C V R}{k}
$$

The number of rating categories affects the content validity standard set by Aiken. The smallest rate of each categories formulated by Aiken is two and the highest is seven (Aiken, 1985). This research uses four rating categories and three raters. Content validity analysis using the Aiken V coefficient was used to test the validity of the observation sheet instrument, with the content validity introduced by Lawshe to test the content validity of the test instrument.

The Aiken validity coefficient is calculated using the raw score of $\mathrm{n}$ experts, while the content validity using the $\mathrm{V}$ Aiken coefficient by Formula (3), where $\mathrm{r}=$ the score given by the rater, $10=$ the lowest rate, $\mathrm{c}=$ the highest rate, $\mathrm{n}=$ the number of raters, and $\mathrm{i}=$ integers from 1, 2, 3 to $n$ (Aiken, 1985).

$$
V=\frac{\sum\left(r_{i}-l_{0}\right)}{[n(c-1)]}
$$

The validity and reliability of the constructs of the indicators (items) formed latent constructs by conducting Confirmatory Factor Analysis (CFA) (Latan, 2012). The construct validity was tested by using $\mathrm{KMO}$ and Bartlett's test of sphericity.

Based on the content and construct validity, the product from the trial results needs to be revised in terms of its content. The revised product was named as draft II. The next stage was field trials, on which a Physics teacher was given the role to analyze the product before it was tried out in the classroom. The product was revised again as draft III in the improvement of product yields stage. After going through an assessment by a construction expert and material, the next stage involved class XI students as research subjects in the field implementation test. During the learning process, the final product improvement stage was carried out simultaneously with the implementation of learning using the revised product. 


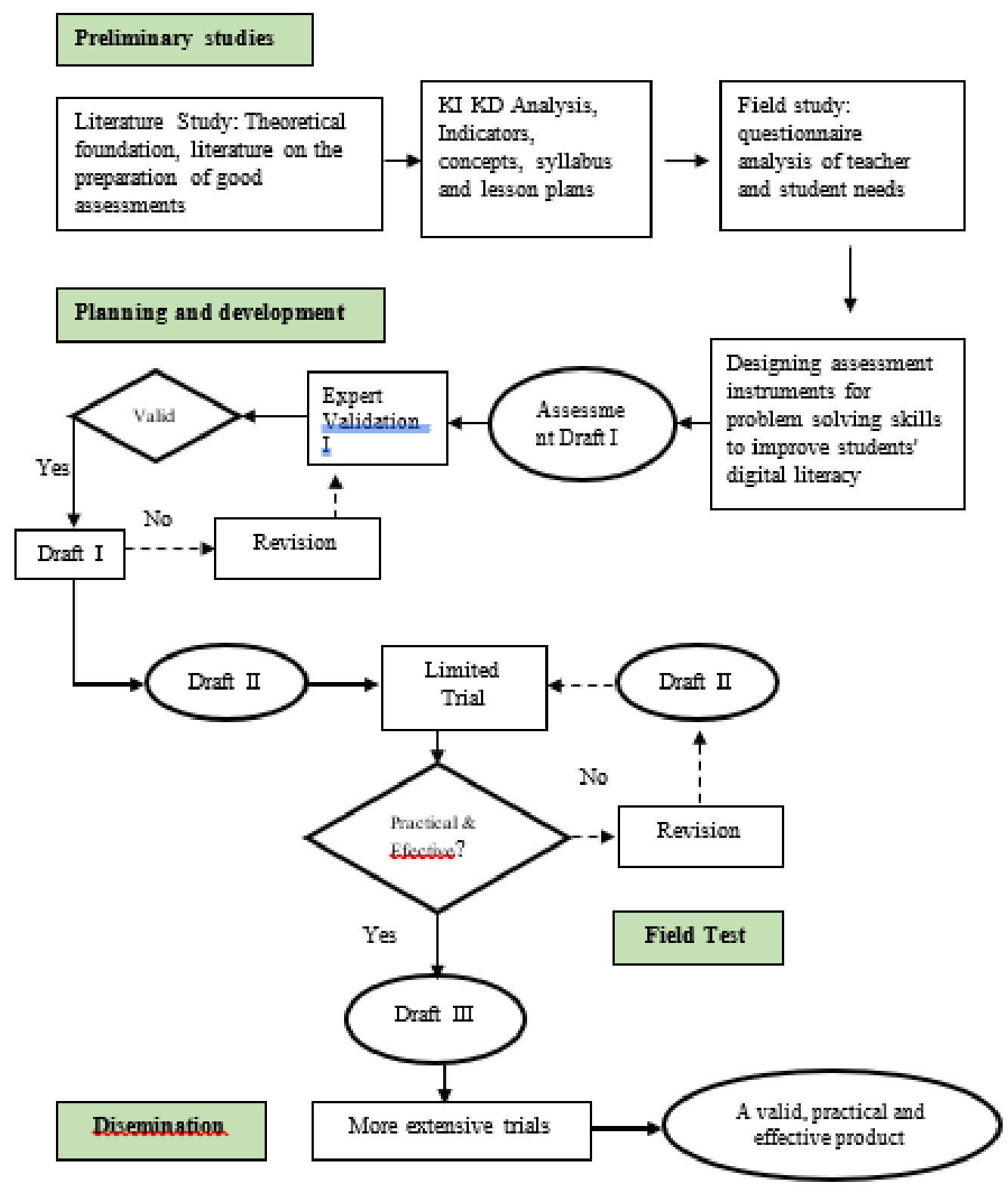

Figure 1. Research Flow Chart

The implementation phase of the research was carried out by following the development model of Borg and Gall (2003), where then the ten steps were grouped into four stages by making adjustments, namely a preliminary study; planning and development; field test; and dissemination. The steps in conducting this research can be seen in Figure 1.

\section{FINDINGS AND DISCUSSION}

This research was conducted by developing a product that will be used in learning process. The product is students' problem skills assessment. The assessment uses the student problem solving skills as a way to improve students' digital literacy skills on each stage of problem solving skills. The research was carried out using a self-assessment that gave rise to five stages of problem solving skills. Students are evaluated on what has been achieved and understood in learning. Assessment by focusing on students skills to remember and conclude what is being analyzed with prior understanding. This assessment is realized in class activities by involving reflection activities and adjusting previously owned concepts. 
Through alternative assessments, learning becomes more authentic because it helps improve students' decision-making skills and problem solving skills (Timmins, 1996). Authentic assessment result data includes information on the strengths and weaknesses of students during the learning process. Data collection generally uses assignments that are close to real dayto-day activities. Authentic assessment helps educators gather views on the effectiveness of learning towards students and make changes to further learning if needed.

The implementation of assessment activities is carried out by the teacher following the stages that have been prepared in the assessment. Before carrying out the assessment activities, the teacher observes students. Observations were made on students in the experimental class and the control class. The teacher pays attention to the students initial conditions before starting learning. Observations are also made by giving several opening questions (pre-test) to students. The results of the initial observation data and pre-test become the initial baseline report before conducting treatment in learning.

Enforcement of learning by using the assessment was carried out in the experimental class, while in the control class is applied as usual learning. In the control class, students use books as a source of information when they want to carry out learning activities.

The students in the experimental class carry out self-assessment activities of problem solving skills by using video learning media that are prepared beforehand the site address and several sources of articles that have been checked before the accuracy of the information on the site. When learning takes place, the teacher makes observations again to measure the extent to which activities that bring up the problem solving skills are carried out among students. The measured problem solving skills of students are used by assisting digital literacy of students, namely by using information sources and learning videos obtained from the internet.

In the aspect of gathering information about a problem, students are directed to gather information with the help of the internet. The teacher provides a link option for digital information sources that students can use to collect information and students are given the opportunity to look for additional information independently from other sources. The process of collecting digital-assisted information is carried out to realize meaning making aspects for students. Students who can collect information about problems through digital information well can be concluded that they can compose meaning in digital information as well. In the aspect of examining problems and compliance with the principles of fluid dynamics that have been studied using information obtained digitally, the teacher observes the students skills to trace and associate information that has been obtained digitally with the problems that are the topic of discussion during learning. In the aspect of finding digital-assisted solutions, the teacher observes students attitudes when conducting a library review of digital information sources that have been obtained previously. In this aspect, the teacher also observes the students to discuss digital information obtained with other students so that a more robust literature study analysis of the digital information sources that has been obtained previously will be formed.

The teacher also observes nine aspects of students digital literacy skills (making meaning, analyzing, persona, use, decoding, creativity, operational skills, information skills, ICT literacy). The observation process was carried out using observation instruments of student behavior by loading nine aspects of the digital literacy skills.

The posttest assessment process took place in both classes using the same instrument at the end of the lesson. The results of observations and tests that have been given are taken into consideration in measuring the improvement of students digital literacy skills in the experimental class.

This research involves class XI students as research subjects, consisting of one class as an experimental class and one control class. The experimental class was treated with learning by using problem solving skills assessment, while the control class carried out learning using books and worksheets as the main source of information throughout the learning process. The design of this study uses the pretest-posttest design from Fraenkel and Wallen (2012), as 
shown in Table 2, where $\mathrm{E}=$ experimental class, $\mathrm{C}=$ control class, $\mathrm{Y} 1=$ pretest on experimental class, $\mathrm{Y} 2=$ posttest on experimental class, $\mathrm{X} 1=$ learning with problem solving assessment, $\mathrm{X} 2$ = learning without problem solving assessment, $\mathrm{Y} 3=$ pretest on control class, and $\mathrm{Y} 4=$ posttest on control class.

Table 2. Pretest-Posttest Design

\begin{tabular}{cccc}
\hline Group & Pretest & Dependent Variable & Postest \\
\hline $\mathrm{E}$ & $\mathrm{Y}_{1}$ & $\mathrm{X}_{1}$ & $\mathrm{Y}_{2}$ \\
$\mathrm{C}$ & $\mathrm{Y}_{3}$ & $\mathrm{X}_{2}$ & $\mathrm{Y}_{4}$ \\
\hline
\end{tabular}

The assessment that was developed was problem solving skills assessment in the Fluid Dynamics subtopic which included the task of tracking the cause of the aircraft being unable to fly through the internet media. The assessment contains learning scenarios, grids, instrument shapes (observation sheets), instrument rubrics, and scoring guidelines to obtain final scores on aspects of students problem solving skills.

The preparation of problem solving skills assessment begins with determining the objectives of the preparation of the assessment, the assessment lattice, the shape and format of the assessment, and the scoring guidelines. Initial testing of the assessment is carried out by initial testing of product design on a limited scale, namely the expert validation test. Lawshe (1975) stated that the minimum recommended number of evaluators is 5 , and in order for the item to be accepted, all the raters must admit that the item is essential.

Based on the research, the number of raters for the validation assessment was three, and all raters stated that the item is essential. Based on Formula (1), CVR index from the assessment is 1 . CVR of each item is 1 and there are 13 items to assess. Based on Formula (2), Content Validity Index is 1 . The CVI value obtained from the average CVR is 1 . Based on the CVR value that exceeds 0.99, all items are declared valid (Lawshe, 1975, p. 568) and are suitable for use for further research.

Table 3.Content Validity Analysis

\begin{tabular}{ccc}
\hline Item & Rater & Aiken's V \\
\hline 1 & 3 & 0.89 \\
2 & 3 & 0.67 \\
3 & 3 & 0.67 \\
4 & 3 & 0.78 \\
5 & 3 & 0.78 \\
6 & 3 & 1 \\
7 & 3 & 0.89 \\
8 & 3 & 0.67 \\
9 & 3 & 0.78 \\
10 & 3 & 0.78 \\
11 & 3 & 0.89 \\
12 & 3 & 0.78 \\
13 & 3 & 0.89 \\
\hline
\end{tabular}

The content validity was analyzed by Aiken's $\mathrm{V}$ for each item, in which the result can be seen in Table 3. Based on Table 3, the results of the validation of each validator can be said to be very high. The average of content validation by Aiken's V is 0.80 . The construct validity is analyzed with SPPS 25 by using KMO and Bartlett's Test.

Based on Table 4, the results of the SPSS output display show that the value of KMO = 0.517 , so that it means that the factor analysis can be carried out. The Bartlett test value with Chi-squares $=1.604$ and significant at 0.659 , so it can be concluded that the factor analysis test can be continued. 
10 - Erlida Amnie, Undang Rosidin, Kartini Herlina, \& Abdurrahman

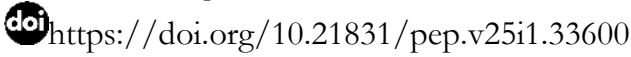

Table 4. KMO and Bartlett's Test

\begin{tabular}{lcc}
\hline Kaiser-Meyer-Olkin Measure of Sampling Adequacy. & .517 \\
Bartlett's Test of Sphericity & Approx. Chi-Square & 1.604 \\
& df & 3 \\
& Sig. & .659 \\
\hline
\end{tabular}

The assessment can be continued to be used with a slight improvement in the learning scenario section. Previous learning scenarios contain questions that must be answered by students but are not included in the column to answer the question but because it is felt to be incorrect, each question is included with a place to answer the question. It aims to make students more challenged to explore their answers.

The number of aspects of the observation that originally contained 18 items was reduced to 12 items because if a teacher uses a problem solving skills assessment that contains 18 assessment items for one student then the teacher will run out of time to assess all students in the class. This is considered ineffective, so the researchers make 12 items on the observation aspect. The researchers improve the scale used in the scoring guidelines and recapitulates the final grade, rubric, writing system, and language as suggested. Overall, on the assessment problem solving skills development results is feasible in terms of construction.

The assessment is suitable to be used after being revised according to the validator's direction. Revised improvements based on the three validator's suggestions for the problem solving skills assessment, which is to add an observation link source or observation that will be done through a video tutorial, clarify the description of the stages of problem solving skills that students want to do, and provide clearer details about the assessment rubric on the assessment. The revision product the known as draft II.

After the product is revised, a field test is then performed. This field test is given to physics subject teachers. This trial was conducted with the aim to determine the validity, effectiveness, and practicality of the use of assessments felt by the user, namely the teacher.

The use of problem solving skills assessment by involving information retrieval using digital sources that have been done also pay attention to aspects of students digital literacy skills at the time of the assessment. Problem solving skills assessment is used in an experimental class by the subject teacher. The teacher does the apperception and presentation of learning material related to the use of the assessment. Use of the assessment is carried out at the second meeting after the teacher ensures students understanding of the material.

Students read and understand the preliminary activities section and description of the first activity in eliciting problem solving skills, namely defining the problem. The students can move to the second stage if they have followed the steps in the first stage, one of them, they are asked to open sources of learning videos and articles related to the main problem.

Students can understand and follow the instructions in the steps easily. The main problem lies in the implementation of the stages in the assessment. In the first stage, the average student takes approximately 40 minutes (one hour of learning) to identify problems based on article searches and results of watching videos.

The implementation of the first stage also has obstacles for some students. The first stage requires internet activation as a medium for information retrieval. Some students claimed not to have a quota to conduct their own searches. Finally, some students did a group search. The information retrieval process carried out is also far from good and long lasting.

Some female students find it hard to watch learning videos and are lazy to read the source of the article provided. They did not like studying Physics from the beginning and already felt dizzy first when studying Physics. In this condition, the teacher just let it go because most students have been able to follow the process of finding information in the first stage. 
Students who have completed the activity in the first stage then proceed to stage two, examining the problem. At this stage, each writes the results of the previous search. When writing down the cause of a plane not flying suddenly, there are some students who repeat the learning video that has been watched previously. Some students also reopen articles that have been searched and some students rely on the results of a one-time search.

During stages one to three, the teacher acts as a facilitator and makes a thorough observation of each student's behavior. The teacher makes observations about aspects of problem solving skills and aspects of students digital literacy skills during the activity. Observations are made by referring to the observation instruments that have been prepared beforehand.

In the fourth stage, students are asked in groups in one bench to discuss the results of each writing from stages two and three. During the discussion, each group draws a plan that is appropriate for the solution of the problem raised. In the final stage of the activity, all students are invited to discuss by describing the results of the discussion on the bench to the search results in stages one to three. At this stage, all students conduct a global check and evaluation of the problems that have been raised.

At the end of the lesson, the teacher gives a posttest to measure student understanding related to the material that corresponds to the problem. In the posttest, the teacher included five questions related to students responses to the assessments and learning activities at that time. Students are also given one question space to write suggestions and hopes for future physics learning. All students understand the stages that exist in the learning process. Students are just not used to it because learning activities involve using the internet directly in class with a time limit. Some students better understand the concepts of physics through simple learning video media that are searched online. Some other students experience technical difficulties because they have not become routine learning activities in the classroom.

The results of the analysis of the experimental class using the stages of digital literacy are the planning stages carried out by students on average by $77.2 \%$, the implementation stage by an average of $75 \%$, and the evaluation stage by an average of $81 \%$. The analysis of the posttest and pretest results are listed in Table 5.

Table 5. T-Test of Pretest Postest for Control Class

\begin{tabular}{|c|c|c|}
\hline Data & Pretest & Postest \\
\hline $\mathrm{N}$ & 30 & 30 \\
\hline Lowest Score & 17 & 26 \\
\hline Highest Score & 41 & 44 \\
\hline Average & 33.13 & 34.35 \\
\hline $\mathrm{T}$ & & \\
\hline Sig. 2- tailed & & \\
\hline
\end{tabular}

The lowest score for the control class at the time of the pretest was 17 and the highest score was 41 . For the posttest, the lowest score was 26 and the highest score was 44 . The results of the $\mathrm{T}$ test show sig. $0.120>0.05$, so $\mathrm{H}_{0}$ is accepted, meaning that the average of the two populations is the same or there is no difference between the pretest and posttest. The results of the T-test in the experimental class are summarized in Table 6.

Table 6. T-Test of Pretest Postest for Experimental Class

\begin{tabular}{|c|c|c|}
\hline Data & Pretest & Postest \\
\hline $\mathrm{N}$ & 30 & 30 \\
\hline Lowest Score & 26 & 58 \\
\hline Highest Score & 42 & 82 \\
\hline Average & 33.57 & 70.70 \\
\hline $\mathrm{T}$ & & \\
\hline Sig. 2-tailed & & \\
\hline
\end{tabular}


Based on Table 6 , the lowest score for the experimental class at the time of the pretest was 26 and the highest score was 42 . For the posttest, the lowest score was 58 and the highest score was 82 . The results of paired sample t-test analysis of the experimental class shows sig. 2-tailed $0.000<0.05$ in the experimental class, so it can be concluded that $\mathrm{H}_{0}$ is rejected.

This means that the average of the two populations is different or there is a difference between pretest and posttest. Based on the aforementioned results of analysis, there is no difference between the pretest and posttest in the control class, while the experimental class shows the difference between the pretest and posttest. The N-Gain test results of students problem-solving skills in the experimental class by 0.3 with a quite effective category higher than the control class of 0.12 with a quite effective category.

Problem solving skills assessment using aspects of digital literacy skills is a way of integrating digital literacy and problem solving in a single learning activity. Through this assessment, students are directed to be skilled in finding and compiling information that will be used to solve some of the problems that have been raised by the teacher previously. Based on the description of the practicality and effectiveness of using the previous assessment of problem solving skills, it is known that students' digital literacy skills have increased, although slowly.

This is in accordance the statement of LINCS Regional Professional Development Center for Adult Education (2015) that integrating digital literacy and problem solving in an instruction (learning activities) can accelerate the student learning process by increasing the use of technology to solve problems raised during learning and will certainly increase students' digital literacy and access. Thus, it can be concluded that the instrument of problem solving skills assessment can help students improve digital literacy so that the learning outcomes of students also increase.

The digital literacy referred to in this research is the learning independence of students using the help of digital information in finding a solution to the problems raised by during the learning process. The aspects that cover digital literacy skills include planning, implementation and evaluation.

In the control class, learning is carried out in a conventional way and in the experimental class, learning is carried out using the problem solving skills assessment instrument. The results of the pretest and posttest showed that in the control class there was no significant increase in scores between the pretest and posttest. The technology used in classroom learning can actually help carry out learning activities better. During the process of learning activities using problem solving skills assessment and covering aspects of digital literacy activities, students are initially directed to use their technology as a source of fulfilling the information needed in learning. This is still felt very slowly during the learning process.

Along with the increasingly skilled students in using technology, it can be ascertained that students' skills to understand learning and digital (information) literacy skills will increase. This is in accordance with the research conducted by Katz et al. (2008) which states that students are able to understand learning materials better and faster along with the skillful use of information technology (digital literacy), are able to generate problem solving during learning, and are able to make better learning process.

Based on the trial results shown in Figure 2, the assessment validity level was $86.67 \%$, the assessment effectiveness level was $71.33 \%$, and the practicality level of the assessment was $71.33 \%$. These results can be said that the level of suitability of the assessment is high, the level of ease of the assessment is high, the level of instrument usability and the level of practicality of the assessment is high.

The assessment is considered to be very practical because the aspects of the skills observed in the assessment are already quite practical in use, meaning that the number of skill aspects in the assessment is not too much but has been able to cover all aspects needed in the assessment therefore the time used in conducting the assessment using the assessment is also not too long. 


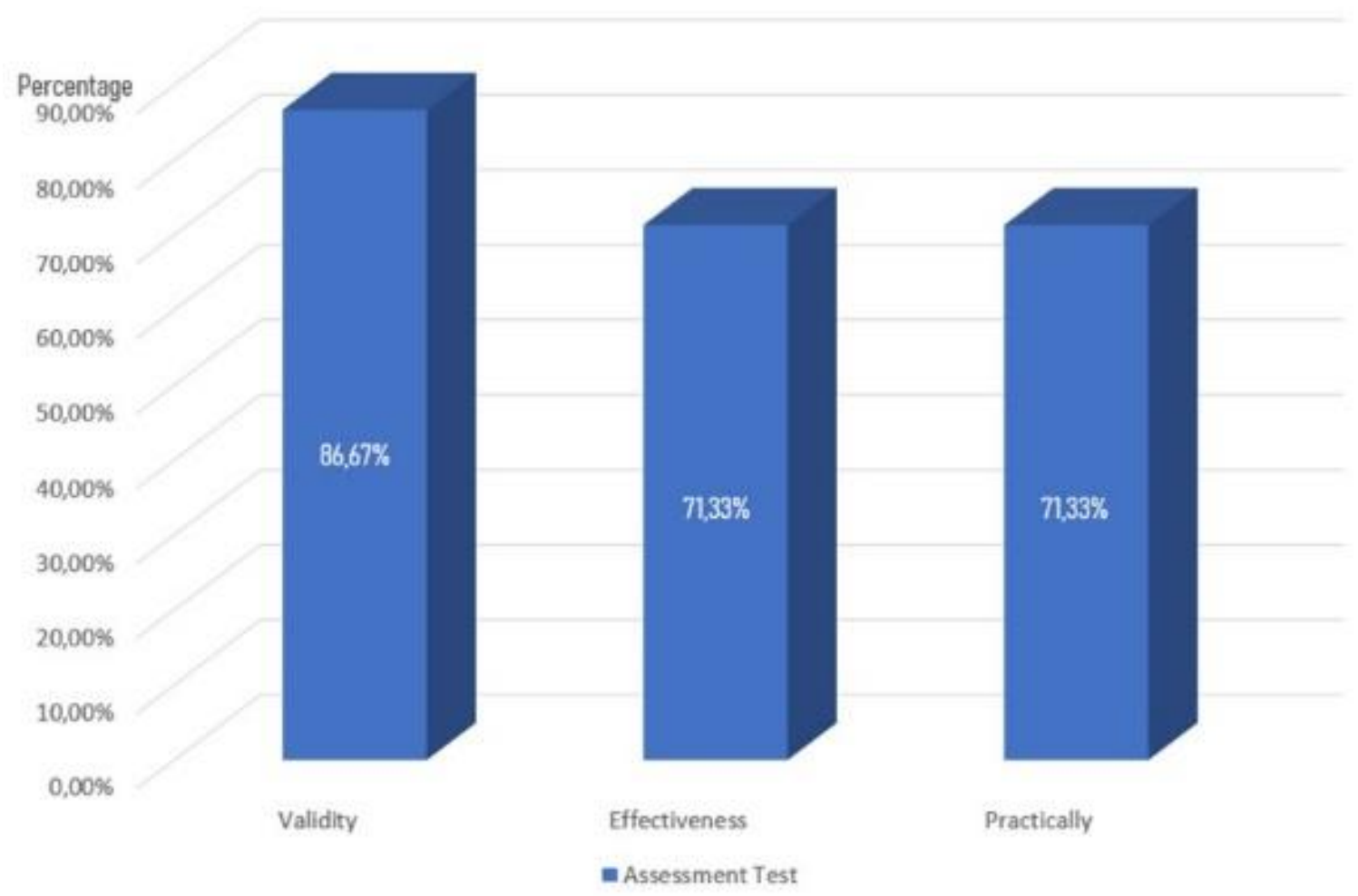

Figure 2. Assessment Test

The scoring aspect of the assessment is also quite practical, because the rubric used is also easy to understand so the assessment is practical to use. The scope of contents and also the design of the assessment is quite practical. The sequential instrument design of the grid, the shape of the assessment, and the assessment rubric make this instrument practical to use and also easy to administer. The problem solving skills assessment is also practical in assessing digital literacy because aspects of digital literacy have been included in this instrument.

The results of the effectiveness test are based on Figure 2 when converted to $71.3 \%$, which means it is very appropriate. The effectiveness of the use of assessments for problem solving skills in improving digital literacy can be determined by comparing learning outcomes or the pretest-posttest scores of the control class and the experimental class. The average pretest score in the control class was 33.13 and the average posttest score was 34.35, while the average pretest score in the experimental class was 33.57 and the average posttest score was 70.70 .

\section{CONCLUSION}

The average of content validation by using Aiken's $\mathrm{V}$ is 0.80 . The construct validity is analyzed with SPPS 25 by using KMO and Bartlett's Test. The results of the SPSS output display show that the value of $\mathrm{KMO}=0.517$, so it means that the factor analysis can be carried out. The Bartlett test value with Chi-squares $=1.604$ and significance at 0.659 , so it can be concluded that the factor analysis test can be continued.

The lowest score for the control class at the pretest was 17 and the highest score was 41 . Besides, for the posttest, the lowest score was 26 and the highest score was 44 . The results of the $\mathrm{T}$ test show sig. $0.120>0.05$, so it can be concluded that $\mathrm{H}_{0}$ is accepted. The lowest score for the experimental class at the pretest was 26 and the highest score was 42, while for the posttest, the lowest score was 58 and the highest score was 82 . The results of the T test show sig. $0.120<0.05$, so it can be concluded that $\mathrm{H}_{0}$ is accepted. 
At the product revision stage based on the use trial, the appraiser responded that this assessment still took a long time because the assessor had to observe each student according to the aspects contained in the assessment rubric. The stage that is assessed cannot be done in one learning process. Each meeting is only able to assess one or two stages of problem solving activities that integrate digital literacy skills. This is one of the reasons for the effectiveness of the use of the assessment developed quite effectively. Teachers and students are not familiar with the assessment of problem solving skills that are developed by integrating these digital literacy skills properly.

\section{REFERENCES}

Aiken, L. R. (1985). Three coefficients for analyzing the reliability and validity of ratings. Educational and Psychological Measurement, 45(1), 131-142. https://doi.org/10.1177/0013164485451012

Bawden, D. (2001). Information and digital literacies: A review of concepts. Journal of Documentation, 57(2), 218-259. https://doi.org/10.1108/EUM0000000007083

Borg, W. R., \& Gall, M. D. (2003). Educational research: An introduction. Longman.

Cullinane, A., \& Liston, M. (2011). Two-tier multiple choice questions: An alternative method of formative assessment for first year undergraduate Biology students. Limerick: National Center for Excellence in Mathematics and Education Science Teaching and Learning (NCEMSTL).

Eshet, Y. (2004). Digital literacy: A conceptual framework for survival skills in the digital era. Journal of Educational Multimedia and Hypermedia, 13(1), 93-106. https://www.learntechlib.org/primary/p/4793/

Eshet, Y. (2002). Digital literacy: A new terminology framework and its application to the design of meaningful technology-based learning environments. In P. Barker \& S. Rebelsky (Eds.), Proceedings of ED-MEDIA 2002--World Conference on Educational Multimedia, Hypermedia \& Telecommunications (pp. 493-498). Association for the Advancement of Computing in Education (AACE). https://www.learntechlib.org/primary/p/10316/

Fraenkel, J., \& Wallen, N. (2012). How to design and evaluate research in education (8th ed.). McGraw-Hill Higher Education.

Frey, B. B., \& Schmitt, V. L. (2007). Coming to terms with classroom assessment. Journal of Advanced Academics, 18(3), 402-423. https://doi.org/10.4219/jaa-2007-495

Gilster, P. (1997). Digital literacy. Wiley Computer Pub.

Heller, P., Keith, R., \& Anderson, S. (1992). Teaching problem solving through cooperative grouping. Part 1: Group versus individual problem solving. American Journal of Physics, 60(7), 627-636. https://doi.org/10.1119/1.17117

Hinrichsen, J., \& Coombs, A. (2014). The five resources of critical digital literacy: A framework for curriculum integration. Research in Learning Technology, 21, 21334-21350. https://doi.org/10.3402/rlt.v21.21334

James, M. (2008). Assessment and learning. In S. Swaffield (Ed.), Unlocking assessment: Understanding for reflection and application (1st ed., pp. 20-36). Routledge.

James, M. (2015). Educational assessment: Overview. In P. Peterson, E. Baker, \& B. McGaw (Eds.), International encyclopedia of education (3rd ed., pp. 161-171). Elsevier. 
Jimoyiannis, A. (2015). Digital literacy and adult learners. In J. M. Spector (Ed.), The SAGE encyclopedia of educational technology (pp. 213-216). SAGE Publication.

JISC. (2014). Developing digital literacies. Joint Information Systems Committee. https://www.jisc.ac.uk/full-guide/developing-digital-literacies

Kartowagiran, B., \& Jaedun, A. (2016). Model asesmen autentik untuk menilai hasil belajar siswa sekolah menengah pertama (SMP): Implementasi asesmen autentik di SMP. Jurnal Penelitian Dan Evaluasi Pendidikan, 20(2), 131-141. https://doi.org/10.21831/pep.v20i2.10063

Katz, I. R., Elliot, N., Attali, Y., Scharf, D., Powers, D., Huey, H., Joshi, K., \& Briller, V. (2008). The assessment of information literacy: A case study. ETS Research Report Series, 2008(1), 1-34. https://doi.org/10.1002/j.2333-8504.2008.tb02119.x

Latan, H. (2012). Structural Equation Modeling: Konsep dan aplikasi menggunakan LISREL 8,80. Alfabeta.

Lawshe, C. H. (1975). A quantitative approach to content validity. Personnel Psychology, 28(4), 563-575. https://doi.org/10.1111/j.1744-6570.1975.tb01393.x

LINCS Regional Professional Development Center for Adult Education. (2015). Integrating digital literacy and problem solving into instruction. LINCS Regional Professional Development Center for Adult Education. https://lincs.ed.gov/professional-development/resourcecollections/profile- 820

Ng, W. (2012). Can we teach digital natives digital literacy? Computers \& Education, 59(3), 10651078. https:// doi.org/10.1016/j.compedu.2012.04.016

Novitasari, N., Ramli, M., \& Maridi, M. (2015). Penyusunan assessment problem solving skills untuk siswa SMA pada materi Lingkungan. Prosiding Seminar Nasional XII Pendidikan Biologi FKIP UNS 2015: Biologi, Sains, Lingkungan, Dan Pembelajarannya, 519-525.

Richards, J. C., \& Renandya, W. A. (Eds.). (2002). Methodology in language teaching: An anthology of current practice. Cambridge University Press. https://doi.org/10.1017/CBO9780511667190

Rust, C. (2002). The impact of assessment on student learning: How can the research literature practically help to inform the development of departmental assessment strategies and learner-centred assessment practices? Active Learning in Higher Education, 3(2), 145-158. https://doi.org/10.1177/1469787402003002004

Son, J.-B., Park, S.-S., \& Park, M. (2017). Digital literacy of language learners in two different contexts. The JALT CALL Journal, 13(2), 77-96. https://doi.org/10.29140/jaltcall.v13n2.213

Taras, M. (2005). Assessment - Summative and formative - Some theoretical reflections. British Journal of Educational Studies, 53(4), 466-478. https://doi.org/10.1111/j.14678527.2005.00307.x

Timmins, A. C. B. (1996). Multiple intelligences: Gardner's theory. Practical Assessment, Research, and Evaluation, 5(1). https://scholarworks.umass.edu/pare/vol5/iss1/10

Tosuncuoglu, I. (2018). Importance of assessment in ELT. Journal of Education and Training Studies, 6(9), 163-167. https://doi.org/10.11114/jets.v6i9.3443

Wiggins, G. (1990). The case for authentic assessment. Practical Assessment, Research, and Evaluation, 2(1), 1-6. https://doi.org/10.7275/ffb1-mm19 